\title{
Plant Variety Protection: A Consideration of Genetic Relationships
}

\author{
Jack E. Staub ${ }^{1}$ \\ Vegetable Crops Research, U.S. Department of Agriculture, Agricultural Research Service, \\ Department of Horticulture, University of Wisconsin-Madison, Madison, WI 53706 \\ August Gabert ${ }^{2}$ \\ Sunseeds Company, Brooks, OR 97305 \\ Todd C. Wehner ${ }^{3}$ \\ Department of Horticultural Science, North Carolina State University, Raleigh, NC 27695-7609
}

\section{BACKGROUND}

Increased interest and debate over ownership of intellectual property (e.g., plant proprietary rights) has arisen in agriculture because the protection of research products is necessary to provide incentive for investment. Any unique, documentable invention (a product, service, or process) having potential use in commerce can be considered intellectual property. Intellectual property is any recorded "invention" arising from "new products, new services and new manufacturing processes no less than artistic works or scientific advances ... which can be bought and sold" (Nicholson Green Paper, 1983). In agriculture, unique inventions can become the property of individuals or organizations. For instance, improved plant varieties are inventions developed by breeders who are skilled in the art/ science of genetic manipulation. Inventions, including varieties, gene processes, or genetic constructs, developed by plant breeders or geneticists can be protected by law.

Concern for comprehensive remuneration, however, has not always been an important issue in varietal development. For example, crossing and selection were practiced by plantsman from around 1870 onwards (Mastenbroek, 1988). At the turn of this century, selections in many crop species were still made from landraces. During the evolution and refinement of breeding techniques between 1900 to 1960, many methods (e.g., backcross and pedigree selection) were developed that led to improved homogeneous and homozygous varieties (Mastenbroek, 1988).

Received for publication 29 Jan. 1996. Accepted for publication 8 Apr. 1996. Mention of a trade name, proprietary product, or specific equipment does not constitute a guarantee or warranty by the U.S. Dept. of Agriculture and does not imply its approval to the exclusion of other products that may be suitable. The cost of publishing this paper was defrayed in part by the payment of page charges. Under postal regulations, this paper therefore must be hereby marked advertisement solely to indicate this fact. ${ }^{1}$ Research Horticulturist and Professor.

${ }^{2}$ Senior Plant Breeder.

${ }^{3}$ Professor.
Species crosses, polyploidy manipulations, induced mutation, and the refinement and use of biological systems, such as male sterility, also led to enhanced germplasm.

As the profitability of seed companies improved, the potential for losses due to theft or infringement also increased. Consequently, economically based issues that needed legal interpretation and regulation emerged. Efforts to resolve these issues led to the enactment of intellectual property rights legislation in the United States and Europe. Currently, plants can be protected in the United States by the Plant Patent Act (PPA) of 1930, the Plant Variety Protection Act (PVPA) of 1970 as amended in 1994, and with utility patents or in Europe by Plant Breeders Rights (PBR) of 1961 (Dworkin, 1988; Jondle, 1989). In the 1980s and 1990s, reinterpretation of law was required to satisfy the protection of products emerging from modern plant biotechnology, e.g., 1994 PVPA amendments; 7 U.S.C.

The intended purpose and perceptions surrounding plant protection varies for the seed industry and farmers depending on the country (Vanhala et al., 1989). For example, plant protection has been viewed as largely undesirable in lesser developed countries because it promotes the monopoly of multinational companies involved in food production (Dixon, 1985). This opinion, however, is not necessarily shared by all seed companies.

The determination of genetic difference is important in plant variety protection because intellectual ideas may be similar and infringement of proprietary rights occasionally occurs. Where a variety of one seed company is thought to infringe upon the proprietary rights of a variety from another company, legal action may result. In cases of alleged infringement, arguments based on scientific fact are proffered and interpreted by the judicial system.

\section{OBJECTIVES}

The primary objective of this paper is to summarize criteria used in plant variety protection and to examine several problems associated with the determination of distinctiveness using genetic markers. Phenotypic appearance, genetic constitution (i.e., pedigree information), and genetic distance (i.e., allelic composition) are key factors used in interpretation of infringement. Genetic distance estimations provide for a measure of the difference (genetic proximity or identity) between two varieties relative to measured characteristics (e.g., color, biochemical genetic markers) (Bretting and Widrlechner, 1995). To probe the relationship between these factors we have briefly summarized the current legal options for plant variety protection and defined certain aspects of genetic distance determination (e.g., criterion for plant description and essentially derived varieties). The information provided herein is not meant to be a comprehensive treatment of the relevance of genetic markers for plant variety protection. Rather, it is meant to provide current information regarding specific issues in plant variety protection relating to genotypic difference. These thoughts will be helpful for workers in private and public institutions involved in determining the future of plant variety protection law in light of biotechnological advances.

\section{Plant variety protection}

Laws. Depending on the type of legal protection, varieties are protected based on their distinctiveness, novelty, stability, uniformity, nonobviousness, and utility. The derivation of a variety is important since its intellectual property rights are based on these criteria. Although very important, definitions of distinctiveness and essential derivation are difficult to apply. The laws governing plant protection are not uniform among countries and this lack of harmony has led to a confusing array of legal options (Ihnen and Jondle, 1989; Jondle, 1993; Williams and Weber, 1989). For the purpose of this paper, proprietary law in the United States and the European Community will be used to illustrate differences in legal application. The United States has five main categories of plant protection: 1) trade secrets, 2) contracts, 3) PPA, 4) PVPA, and 5) utility patents (Jondle, 1993, 1994).

Trade secrets and contracts are governed by state law that determines the strength of such protection. Thus, law involving trade secrets can vary widely (Jondle, 1994). Trade secrets can be applied to any confidential information, process, or germplasm that gives a company a documentable competitive ad- 
vantage. Trade secrets can provide protection for technologies that are never publicly disclosed, or technologies that are under patent application (Ihnen, 1989).

Contracts can be formed as licensing agreements, secrecy agreements, condition of sale agreements, and "restricted use" labels on commercial seed bags (Jondle, 1994). It is uncertain what level of protection contracts provide; thus, the strength of contracts must be determined by the courts on a case by case basis.

The PPA can be used by breeders to prevent the sale of new and distinct asexually propagated plants (Jondle, 1994). It does not provide protection for seeds, tubers, plant parts, biotechnology processes, recombinant DNA, or genes.

In contrast, PVPA offers protection for unique, sexually reproduced cultivars and inbred parents of hybrids based on novelty, uniformity, stability, and distinctiveness (Jondle, 1994). The 1994 amendments include changes in eligibility (sexually reproduced plants and tuber-reproduced plants), exclusions (not bacteria or fungi), priority (first to file), length of protection ( 20 years for most species, but 25 years for trees, shrubs, and vines), what is protected (the variety, varieties essentially derived from the variety, harvested material of the variety), and the farmer's exemption (if seed is bought from owner or saving seed only).

Utility patents provide a broad range of protection since, "any new and useful manufacture, or composition of matter, or any new and useful improvement thereof" (under 35 USC 101) is potentially patentable. Proteins, genes, gene fragments, DNA, RNA, microorganisms, transformed cells, plants, plant parts (e.g., seeds, pollen, fruit, flowers), cultivars, hybrids and chemicals, as well as processes that are used in the production of the foregoing, can be protected by utility patents based on their novelty, utility, and nonobviousness (Jondle, 1994).

Licensing of intellectual property has wide application to the various forms of plant variety protection (Jondle, 1994). Licenses provide the licensee the right to use something owned by the licensor without interference from the licensor. The transfer of rights through licensing can provide for broad (i.e., all rights) or narrow (i.e., severely restricted transfer) application of the entity to the licensee. Licenses are governed by either state (e.g., in the United States) or national laws, depending upon the country of their origin.

European plant protection law has an interesting and unique origin. The drafting of the document "Union pour la protection des obtentions vegetales" at the International Convention on the Protection of Plant Varieties (UPOV) in Paris, 1961 (Beier and Straus, 1986), was significant in this regard because the inapplicability statement for plants under the Strasbourg Convention (patenting of abiotic inventions) was incorporated into the European Patent Convention (EPO) of 1973 (Vanhala et al., 1989). The UPOV document is pivotal to plant patenting in Europe and forms the basis of proprietary rights legislation for its European signatories (currently 24). More recently, signatories (e.g., Kenya, South Africa, New Zealand, and the United States) have been added, which extends the convention's international influence. The convention is directed by an international seed trade association, International Association of Plant Breeders for the Protection of Plant Varieties (ASSINSEL), of which the American Seed Trade Association (ASTA) is a member.

The original UPOV Convention has been amended numerous times, resulting most recently in the 1991 Act of the Convention. Signatories of this convention recognized the protection of plants under "Plant Breeder's Rights," which qualifies varieties based on distinctness, stability, and uniformity. Signatories may retain or revise their national restrictions and laws relating to plant protection, but take on UPOV Conventions when working within the European Community. There is, however, uncertainty regarding the scope of protection available in Europe for inventions in plant biotechnology (R.C. Peet and S.A. Bent, personal communication, 1996). This uncertainty has been made clear in the recent controversial decision by the Technical Board of Appeal, T 0356/93 ("Plant Cells/Plant Genetic Systems"), which is the Enlarged Board of Appeal (EBA) at the European Patent Office (Munich, Germany). In this case, legal argument arises as a result of the European patent 0246236 that describes the introduction of a DNA construct into a plant. This construct confers resistance to a herbicide that inactivates the enzyme glutamine synthetase (EC 6.3.1.2; catalyzes 1-glutamate + ammonia to l-glutamine). The UPOV convention for variety protection requires the multiplicity of homozygous plants. Transgenic plants may be stable for a characteristic resulting from a transformation, but it may not be possible to propagate identical plants because of their lack of homozygosity. Although the legal arguments are beyond the scope of this paper, it is clear that the EBA's conclusion is at odds with the description of "variety" contained in the 1991 UPOV text. Plant molecular biology innovations are typically limited to specific plant species and, therefore, protection under UPOV is often not satisfactory.

Protection criteria. Although the PPA and PVPA give no definition of variety peculiar to the law, the recent dictionary definition is "an instance of differing in nature, form or quality," and would likely be used in combination with a definition used in an earlier sense as "a group having certain qualities in common which distinguish it from a larger class to which it belongs..." (Webster's Encyclopedic Dictionary, 1990). These definitions (i.e., ASSINSEL and those that might be used in conjunction with the PPA and PVPA) and the criterion upon which a particular type of protection is given (e.g., distinctiveness, uniform and stable) form the basis for discussions concerning the estimation and application of genetic distance.

The unique character of varieties is common to all plant protection methods. The nov- elty (new, not previously known publicly) criterion in PVP and utility patent applications is similar. However, the distinctiveness criterion of PVP (difference in one or more characteristics) does differ from the nonobviousness (not an obvious variation of the known art) criterion found in utility patent applications (Jondle, 1989, 1993). Article 6 of the UPOV Convention is similar to PVP in its application of distinctiveness criteria (i.e., types are clearly distinguishable from any other variety whose existence is a matter of common knowledge). In each case where the distinctiveness criterion is applied, legal interpretation of minimum distance between genotypes has not been defined (Jondle, 1989). Thus, changes in any documented trait may allow for PVP certification. In contrast, the 1991 UPOV Convention stipulates that certain varieties that are directly derived from other varieties (i.e., "essentially derived" varieties) while distinct from an existing variety cannot be marketed free of infringing the rights of the developer of the prior variety without obtaining a license. This dependency system has been introduced in an effort to reduce the level of varietal "plagiarism" that occurs in the seed industry (Schapaugh, 1989).

Use ofmorphological and molecularmarkers to define distinctiveness. Morphological or biochemical traits that describe phenotypic or genotypic variation can be used to determine distinctiveness or nonobviousness (Staub and Meglic, 1993). Qualitatively and quantitatively inherited morphological traits have been used successfully to describe a large number of varieties in various crop species. Phenotypic character expression is, however, influenced by inter- and intralocus interactions, as well as genotype $\times$ environment interactions. Thus, the use of phenotypic traits for the estimation of genetic distance can be problematic since phenotype may not always be a simple expression of genotype. The potential for unexplained epistatic and environmental interactions with phenotype can present problems not only during PVP or patenting application, but also in cases of alleged infringement of property rights.

Potential problems regarding the measurement of morphological characters can be partially overcome if repeated measurements are made (i.e., replication, repetitions) in multiple environments (i.e., locations, seasons and years). Although this type of comparative description requires substantial resource investment, it has been useful for the varietal characterization of several high-value crop species. For example, candidate cereal varieties in the United Kingdom are evaluated on distinctiveness, uniformity, and stability (DUS) in the $\mathrm{F}_{8}$ generation over locations and years (Jarman and Hampson, 1991). Character assessment of about 40 traits (e.g., plant growth habit, flag leaf attitude, awn coloration, plant height, ear row number) using a maximum of nine levels of quantification (e.g., short, short-medium, medium, etc.) has been regularly applied during examination for 25 years. Groups of characters are used as "class width" variables and these are used to distinguish varieties within a group. Class width or minimum distance is 
defined as "that distance between two varieties for a particular character which is regarded as meaningful by the crop experts."

These distance measures are quantitative and relatively consistent, but rely on subjective assessment (Jarman and Hampson, 1991). A clear distinction can be made between class width, minimum distance, and statistical tests [i.e., least significant distance (LSD)]. Statistical differences determined by LSDS are used as an additional distance measurement between two varieties within a stated minimum distance group. Nevertheless, the minimum distance used to describe the difference between two varieties is not strictly a genetic distance because allelic information is not used solely in its determination (i.e., the genetic component of varietal performance has not been separated from the total phenotypic variation).

In addition to DUS characterization, a variety must be entered on a national list that signifies that it has shown an improvement in field performance or suitability [i.e., value for cultivation and use (VCU)] (Jarman and Hampson, 1991). The combination of DUS and VCU enables member states of the European Community to combine their national lists and trade freely among themselves. In the United States, however, public release procedures vary with institution (universities or government) and PVP certification is based on information available to a U.S. Dept. of Agriculture plant examiner or, in the case of patenting, to a patent examiner. In each case, comprehensive comparative information (e.g., objective, quantitative, replicated data) upon which protection is given may be limited.

An alternative method for describing distinctness or nonobviousness is the use of quantifiable biochemical techniques that are not modified by environment (Staub and Meglic, 1993). If genetic markers are reproducible and can be assigned a predictable genetic basis, they can be effective in determining genetic distance (ASSINSEL, 1994a; Staub and Meglic, 1993). Properly characterized and documented biochemical genetic markers, such as isozymes, restriction fragment length polymorphisms (RFLPs), and, more recently, random amplified polymorphic DNAs (RAPDs) and simple sequence repeats (SSRs) are likely to play an increasingly important role in augmenting and enhancing the genotypic description of varieties.

\section{Genetic distance}

Genetic distance estimation is important in the determination of distinctiveness and essential derivation (Nei, 1987; Weir, 1990; Wright, 1978). Genetic distance can be defined as that difference between two entities (i.e., plant varieties) that can be described by allelic variation (Nei, 1973). The differences between varieties can be determined by an examination of morphological and DNA characteristics. Genetic information regarding the identity of individuals can be obtained from polymorphic and monomorphic loci.

The terms absolute genetic distance, relative genetic distance, and functional genetic distance can be used to better understand the legal implications of genetic distance estimation. Absolute genetic distance is a perfect reflection of reality and is based on a locus by locus assessment of genomic differences (or similarities) between two entities. In contrast, relative genetic distance is that subset of information that describes what is known of "reality" based on the data set used in distance calculations. It is obvious that, at present, measurement of absolute genetic distance is not possible and that the distance calculated between two entities is really a relative distance value.

Functional genetic distance is the point at which the cumulative effect of molecular markers in a mapped genome accounts for a significant amount of the observed variation for a trait (Staub and Meglic, 1993). The calculation of functional genetic distance requires not only a detailed understanding of the genome but also an extensive database on variety performance. Some crop species have large databases to draw on and may be candidates for exploring the concept of functional genetic distance (e.g., cereals; Jarman and Hampson, 1991).

Application of genetic distance measures. The genetic distance between two varieties is a function of relatedness (i.e., pedigree, genetic similarity). Coefficients-of-parentage, quantitative morphological characters, as well as discrete morphological and biochemical characters have been used to determine genetic relationships (Smith, 1984; Souza and Sorrels, 1989). These methods can produce differing relative measures of genetic relationships (Souza and Sorrells, 1991a, 1991b).

Genetic relationships can be examined by estimating and comparing genetic distances using morphological or molecular markers. Various methods have been used to estimate genetic diversity (Cowen and Frey, 1987; Martinez et al., 1983; Smith, 1984; Souza and Sorrels, 1989). Several of these methods have been applied to molecular marker data (Gower, 1985; Jackson et al., 1989; Mumm and Dudley, 1994; Smith and Smith, 1989). Likewise, estimators of genetic distance have been applied for measurement of associations between germplasms (Dudley 1994; Skroch et al., 1992; Weir, 1990). Among the most commonly used estimators of genetic relationships are Rodgers' distance (Messmer et al., 1991; Rodgers, 1972), a similarity coefficient developed by Nei and Li (1979), Nei's distance(D) (Nei, 1973, 1987), the compliment of Jaccards coefficient (Debener, 1990), the percent similarity between entities (Neuhausen, 1992), and Nei's identity (I) (Nei, 1987).

The estimators proposed by Rodgers (1972), Neuhausen (1992), and Nei (1973, 1979, 1987) can be applied to locus-allelic frequency data (Lee et al., 1989; Peterson et al., 1994; Spooner et al., 1992). In the absence of allelic frequency data, the band phenotypes of DNA-based marker systems are scored as absent or present. For codominant markers, distance estimators, such as those of Rodgers (1972) and Neuhausen (1992), can be used to determine genetic proximity. For dominant markers (e.g., RAPDs), ratio combinations (band presence or absence) can be obtained by using simple contingency tables (Gower, 1985; Jackson et al., 1989; Skroch et al., 1992). If one applies Nei's (1987) interpretation of the probability of random allelic co-occurrences, estimators developed by Nei and Li (1979) and Jaccard's coefficient (Jaccard 1908; Jackson et al., 1989) can be applied for genetic proximity determination (Ajmone-Marsan et al., 1992; Debener et al., 1990; Smith et al., 1990; Thormann et al., 1990).

Sample variance in estimation of genetic relationships occurs when a random subset of variables (e.g., morphological characteristics or molecular marker bands) does not equal the value that would be obtained from sampling the entire population being examined. An estimation of the error variance is important in describing relationships since the magnitude of the variance of diverse germplasm is disproportionately large when compared to the variance that often exists among closely related inbred lines. The larger the number of random measurements used (e.g., number of marker bands), the more uniform will be the distribution of values taken from the subset of the population. The use of many markers will reduce the variance estimation of genetic relationships due to over- or under-sampling certain regions of the genome (Tivang et al., 1994). Nevertheless, the experimental error associated with molecular marker data can be considerable (0\% to $10 \%$ ) (Heun and Helentjaris, 1993; Smith et al., 1994; Thormann et al., 1994; Weeden et al., 1992). Thus, the value of genetic distance estimates would be increased if they were accompanied by variance estimates. Variances associated with distance estimations are, however, ratios of complex quadratic functions and are rarely documented (Nei, 1987; Weir, 1990). As a consequence, Weir (1990) has recommended the use of numerical resampling methods (i.e., bootstrapping; Efron and Tibshirani, 1986, 1991) for significant difference testing.

Depiction of genetic distance estimations. Absolute measurements of morphological (e.g., quantitative) and biochemical characters (e.g., qualitative) can be used in genetic distance estimation to provide an estimate of genetic relationships (Souza and Sorrells, 1991a, 1991b). Often, transformed or nontransformed data sets are subjected to multivariate analysis to provide for an examination of genetic relationships. Principal component analysis (PCA), multidimensional scaling (MDS), or cluster analysis are multivariate techniques that are often applied in germplasm evaluation (Carroll and Arabie, 1980; Rao, 1964). PCA and MDS are used to identify similar entries (by mathematical manipulation of original values) and provide an opportunity to reduce the size of a data set for subsequent analysis. The results of PCA (i.e., eigen values) can be used in cluster analysis to provide a two-dimensional pictorial representation of the observed variation (Gower, 1967). Genetic distance estimates also can be subjected to MDS (i.e., using a similarity matrix) directly to produce a twodimensional representation of scaled genetic 
relationships (i.e., using a goodness of fit statistic of stress within the scalar projection of data points) (Green and Rao, 1972; Schiffman et al., 1981).

Multivariate techniques have proven useful for identifying patterns in large data sets. Nevertheless, the statistical analysis of difference among entities can be difficult. Confidence intervals can be calculated for individual entities and used for comparison. Oneway analysis of variance can also be applied on a comparison by comparison basis. The question, however, that will always be raised in cases of varietal infringement is the probability of making Type I (varieties are the same when in fact they are not) or Type II (varieties are different when in fact they are the same) errors. Moreover, statistical estimates of error, although scientifically valid, may not provide the type of precision that the judicial system may demand (i.e., beyond a reasonable doubt).

\section{Defining essential derivation}

A recent ASSINSEL position paper indicates that the decision of distinctness and the consequent granting of protection rests on official government services, while "the demonstration of essential derivation is the business of the holder of the right of the presumed initial variety" (ASSINSEL, 1994a). If it is incumbent on the originator of an initial variety to demonstrate essential derivation, then what scientific and legal framework affords such a demonstration? Do criteria used in the determination of distinctiveness during PVP differ from those used for the determination of essential derivation? ASSINSEL considers distinctness and essential derivation as two distinct juridical concepts (ASSINSEL, 1994a). It suggests that: 1) the assessment of distinctness is based on difference, by the expression of at least one characteristic; 2) the assessment of essential derivation is based on conformity, based on almost all the genome and on most of the essential characteristics resulting from that genome; and 3) the question of distinctness is a question of granting the right of protection, whereas the question of essential derivation is a question of the scope of protection.

ASSINSEL believes that, "it is necessary as far as possible to use different tools for defining distinctness and essential derivation, that distinctness should be assessed with the help of morphological and physiological characteristics," and that, "essential derivation is particularly a question of genotype, and a useful tool to assess it is DNA analysis..." (ASSINSEL, 1994a). The vegetable section of ASSINSEL supports this position, and adds that, "molecular markers should be used for distinction only in an additional and noncompulsory manner." This caveat does not apply to cases of infringement where varietal differences may be defined by essential derivation criteria. A company may proffer the phenotypic and morphological characteristics of the infringed variety, but "a simpler and surer technique such as the use of molecular markers" may be necessary for a more critical assessment of genetic difference. "Molecular markers will certainly become the preferred method of choice to prove essential derivation."

The use of molecular markers in assessing the genetic distance between closely related cultivars can be illustrated in cucumber (Cucumis sativus L.). The monoecious, indeterminate cucumber line AR 79-75 ('Little John'; Univ. of Arkansas, Fayetteville) possesses little leaves ( $l l$; area of first fully expanded leaf $\approx 30$ to $40 \mathrm{~cm}^{2}$; Staub et al., 1992) and a multiple lateral branching habit. Three lines, H-19 ( $l l$; 'Arkansas Little Leaf'), WI $1983(l l)$, and WI 1983 ( $L L$; area of first fully expanded leaf $\approx 80$ to $100 \mathrm{~cm}^{2}$; Staub et al., 1992), were derived from AR 79-75. Monoecious 'Arkansas Little Leaf' (experimental line $\mathrm{H}-19$ ) resulted from nine generations of self- and sib-pollination directly from inbred line AR 79-75. It is, therefore, considered essentially derived from AR 79-75. It was given a PVP certificate in 1993 based on its miniature-sized leaves (mature blade of the third leaf from the terminal whorl being 43 $\mathrm{mm}$ long and $63 \mathrm{~mm}$ wide) and the diameter of its stems (one-third to one-half smaller than other standard cucumber varieties). Also unique to 'Arkansas Little Leaf' is its distinctive multiple branching habit that is not present in standard commercial varieties.

Nearly isogenic lines WI $1983(l l)$ and WI 1983 (LL) were constructed by crossing AR 79-75 to WI 1983, a multiple-disease-resistant, gynoecious, processing cucumber line with standard-sized leaves $(L L)$ (Peterson et al., 1986). This cross was followed by four backcrosses of $l l$ progeny to original WI 1983 $L L$ (recurrent parent). Backcross progeny were self-pollinated during each backcross generation to recover little leaf $(l l)$ genotypes. At $\mathrm{BC} 4$, progeny were self-pollinated and the resulting largest $L L$ and smallest $l l$ segregants were self-pollinated twice to ensure true little leaf character.

Forty mapped RAPD markers (Kennard et al., 1994) were used to assess the genetic distance between all lines derived from AR 79-75 (Staub, 1994). The commonly used indeterminate cultivar Calypso having normal $(L L)$-sized leaves also was evaluated. Genetic distances were calculated using the procedures of Nei (1987), Nei and Li (1979), and Rogers (1972). Analyses indicated that genetic differences exist between the closely related and essentially derived lines examined in this study (Fig. 1). The genetic relationships resolved by the various distance estimators were similar. In each case, the essentially derived lines (AR 79-75 and 'Arkansas Little Leaf') shared the shortest genetic distances (Rogers $=0.12, \mathrm{Nei}$ and $\mathrm{Li}=0.22$, and Nei's I $=0.22$ ). In contrast, the distance between 1983 $l l$ and $1983 L L$ was unpredictably large (Rogers $=0.38$, Nei and Li $=0.48$, and Nei's I $=0.48$ ) considering that, in theory, the genotype of backcross lines should be $\approx 97 \%$ that of the recurrent parent.

The essentially derived line "Arkansas Little Leaf' H-19 was predictably close to AR 79-75
(Fig. 1). However, both morphological and biochemical characteristics indicate that the nearly isogenic lines are phenotypically and genotypically dissimilar. This disparity might be partially explained if the little leaf gene were associated (i.e., linkage, pleiotrophy, or both) with other plant characteristics. In fact, WI $1983 \mathrm{ll}$ does share some characteristics in common with 'Arkansas Little Leaf' and AR 75-79 that are not present in WI 1983 LL. For instance, WI $1983 \mathrm{ll}$ not only has little leaves, but also a small stem diameter and multiple branching habit like 'Arkansas Little Leaf' (unpublished data) — none of which are present in WI $1983 L L$. This example illustrates that the assignment of the distinctiveness criterion and legal interpretation of essential derivation may be complex.

The proposed unilateral use of molecular markers for the assessment of a cultivar's distinctiveness may not be held by all segments of ASSINSEL. For instance, at the second meeting of the Technical Working Group on Biochemical and Molecular Techniques (DNA-profiling in particular) (BMT; 1994b), the U.S. Plant Variety Protection Office (PVPO) and representatives from other countries opposed this position. The PVPA of 1970 (as amended in 1994) requires a variety to possess a clear difference for a variety to be distinct; it does not give the PVPO authority to pick and choose among types of difference. It can be argued that since the 1991 UPOV Convention includes a provision that distinctness is a matter of "phenotype" (visually observed), which is itself an expression of "genotype" (having a genetic basis), no potential distinction can be detectable without having expression. The rationale for this argument rests partially on the fact that substantial portions of DNA do not code for proteins (i.e., expression). Moreover, small changes in morphology are already evident in varieties, and these products are being claimed to be worthy of protection. Such observable expressions of genotype are indeed accepted as evidence of distinctness. Therefore, the BMT suggests that it is not reasonable to hold DNA-based evidence to a more rigorous standard than is applied to morphological evidence. The Maize (Zea mays L.) Section of ASSINSEL supports BMT by recommending that isozyme electrophoresis be used in measuring the distinctiveness of a variety provided that it is accompanied by a hierarchical classification of characteristics (ASSINSEL, 1994a). The major concerns of this ASSINSEL section is that any genetic marker be repeatable, heritable, and that it must be equally applicable to issues of homogeneity and stability.

ASSINSEL recognizes that with a highly variable crop species, close phenotypes can be obtained having different genotypes (ASSINSEL, 1994a). This fact presents technical and financial problems for the seed industry if DNA profiling obligations are enacted through legislation. Although DNA profiling will provide increased information regarding the conformation and control of varietal uniformity and stability, it will add to the expense of varietal development and likely 

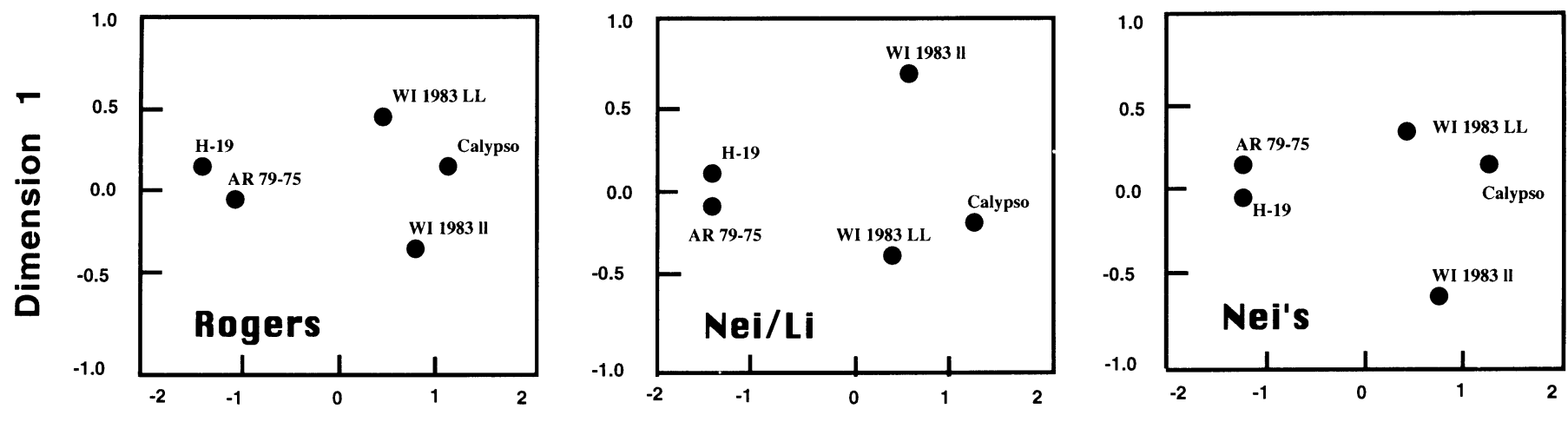

Dimension 2

Fig. 1. Comparisons of genetic distance estimations among cucumber inbred lines using the estimators of Rogers (1972), Nei/Li (1979), and Nei (1973) and multidimensional scalar projection.

narrow the scope of legal protection. The increased financial burden presented by compulsory DNA profiling would not be particularly attractive to many small seed companies with restricted research budgets.

Molecular assessment of genetic difference is quantitative (band absent or present) and its interpretation is unaffected by environment when the observed polymorphisms have a genetic basis and experimental conditions are rigorously controlled. Nevertheless, quantification of genetic difference based on any molecular descriptor is subject to sampling or technical error. Sampling error can be minimized by scoring a large number of individuals and by replication. A PVP application can be strengthened when molecular markers are used in conjunction with stable, well-documented phenotypic descriptors that describe the distinctiveness of a variety.

In cases of alleged infringement, DNA profiling can provide estimates of genetic distance for varietal distinctness. In such cases, it is essential that the variances of genetic distance estimates be provided to allow for critical judicial examination of varietal relatedness. The worth and validity of such information will likely require a case by case appraisal of historical evidence, pedigrees analysis, and an assessment of statistical probabilities of allelic frequency. In the last analysis, rigorous legal interpretation will only be possible when cumulative biological evidence is weighed against existing law. Plant protection law will be refined as precedents are made.

\section{Literature Cited}

Ajmone-Marsan, P., C. Livini, C.M.M. Messmer, A.E. Melchinger, and M. Motto. 1992. Cluster analysis of RFLP data from related maize inbred lines of the BSSS and LSC heterotic groups and comparison with pedigree data. Euphytica 60:139-148.

ASSINSEL. 1994a. Report of meetings of the working groups and sections. Proc. ASSINSEL Congress Ostend, Belgium, 1-3 June, p. 17

ASSINSEL. 1994b. Report of the ASSINSEL technical working group on biochemical and molecular techniques. ASSINSEL biochemical and molecular techniques subcommittee report II. Versailles, France, March.

Beier, F. and J. Straus. 1986. Genetic engineering and industrial property. Industrial property.
86:447-459.

Bretting, P.K. and M.P. Widerlechner. 1995. Genetic markers and horticultural germplasm management. HortScience 30:1349-1356.

Carroll, J.D. and P. Arabie. 1980. Multidimensional scaling. Annu. Rev. Psychology 31:607-649.

Cowen, N.M. and K.J. Frey. 1987. Relationships between three measures of genetic distance and breeding behavior in oats (Avena sativa $\mathrm{L}$.) Genome 29:97-106

Debener, T., F. Salamini, and C. Gebhart. 1990. Phylogeny of wild and cultivated Solanum species based on nuclear restriction fragment length polymorphisms (RFLPs). Theor. Appl. Genet. 79:360-368.

Dixon, D. 1985. Chemical giants push for patents on plants. Science 228:277-280.

Dudley, J.W. 1994. Comparison of genetic distance estimators using molecular marker data. Proc. Joint Symp. Crop Sci. Soc. of Amer. and Amer. Soc. of Hort. Sci. Corvallis, Ore. p. 1-7.

Dworkin, G. 1988. Plant breeders rights and patents for plants and other life forms. Fourth Conf. on Intellectual Property of New Plant Varieties and Biotechnological Inventions, Univ. of London.

Efron, B. and R. Tibshirani. 1986. Bootstrap methods for standard errors, confidence limits, and other measures of statistical accuracy. Stat. Sci. 1:54-77.

Efron, B. and R. Tibshirani. 1991. Statistical data analysis in the computer age. Science 253:390395.

Gower, J.C. 1967. A comparison of some methods of cluster analysis. Biometrics 23:623-637.

Gower, J.C. 1985. Measures of similarity, dissimilarity, and distance, vol. 5, p. 397-405. In: S. Kotz and N.L. Johnson (eds.). Encyclopedia of statistical sciences. Wiley, New York.

Green, P.E. and V.R. Rao. 1972. Applied multidimensional scaling. Holt, Rinehart, and Winston, New York.

Heun, M. and T. Helentjaris. 1993. Inheritance of RAPDs in F1 hybrids of corn. Theor. Appl. Genet. 85:961-968.

Ihnen, J.L. and R.J. Jondle. 1989. Protecting plant germplasm: Alternatives to patent and plant variety protection. Intellectual property rights associated with plants. Amer. Soc. Agron., Madison, Wis. ASA Spec. Publ. 52.p. 123-143.

Jaccard, P. 1908. Nouvelles recherches sur la distribution florale. Bul. Soc. Vaud. Sci. Nat. 44:223270.

Jackson, D.A., K.M. Somers, and H.H. Harvey. 1989. Similarity coefficients: Measures of cooccurrence and associations of simple measures of occurrence. Amer. Nat. 133:436-453.

Jarman, R.J. and A.G. Hampson. 1991. The use of a computer management system for testing candi- date cereal varieties for distinctness, uniformity and stability and the award of plant breeders rights. Plant Var. Seeds 4:161-168.

Jondle, R.J. 1989. Overview and status of plant proprietary rights, p. 1-15. In: B.E. Caldwell, J.A. Schillinger, J.H. Barton, C.O. Qualset, N.N. Duvick, and R.F. Barnes (eds.). Intellectual property rights associated with plants. Amer. Soc. Agron., Madison, Wis. ASA Spec. Publ. 52.

Jondle, R.J. 1993. Legal protection for plant intellectual property. HortTechnology 3:301-307.

Jondle, R.J. 1994. Intellectual property rights in a global market. HortTechnology 4:124-125.

Kennard, W.C., K. Poetter, A. Dijkhuizen, V.Meglic, J.E. Staub, and M.J. Havey. 1994. Linkages among RFLP, RAPD, isozyme, disease-resistance, and morphological markers in narrow and wide crosses of cucumber. Theor. Appl. Genet. 89:92-98.

Lee, M., E.B., Godshalk, K.R. Lamkey, and W.W. Woodman. 1989. Association of restriction fragment length polymorphism among maize inbreds with agronomic performance of their crosses. Crop Sci. 29:1067-1071.

Martinez, O.J., M.M. Goodman, and D.H. Timothy. 1983. Measuring racial differentiation in maize using multivariate distance measures standardized by variation in F2 populations. Crop Sci. 23:775-781.

Mastenbroek, C. 1988. Plant breeders rights on equitable legal system for new plant cultivars. Expt. Agr. 24:15-30.

Messmer, M.M., A.E. Melchinger, M. Lee, W.L. Woodman, E.A. Lee, and K.R. Lamkey. 1991. Genetic diversity among progenitors and elite lines from the Iowa stiff stalk synthetic (BSSS) maize population: Comparison of allozyme and RFLP data. Theor. Appl. Genet. 83:97-107.

Mumm, R.H. and J.W. Dudley. 1994. A classification of 148 U.S. maize inbreds: I. Cluster analysis based on RFLPs. Crop Sci. 34:842-851.

Nei, M. 1973. Analysis of gene diversity in subdivided populations. Proc. Natl. Acad. Sci. USA 70:3321-3323

Nei, M. 1987. Molecular evolutionary genetic. Columbia Univ. Press, New York.

Nei, M. and W. Li. 1979. Mathematical model for studying genetic variation in terms of restriction endonucleases. Proc. Natl. Acad. Sci. 76:52565273.

Neuhausen, S. 1992. Evaluation of restriction fragment length polymorphism in Cucumis melo. Theor. Appl. Genet. 83:379-384.

Nicholson Green Paper. 1983. Intellectual property rights and innovation. 1983 Cmnd.9117. HMSO, Norwich.

Petersen, L., H. Ostergard, and H. Giese. 1994. Genetic diversity among wild and cultivated 
barely as revealed by RFLP. Theor. Appl. Genet. 89:676-681.

Peterson, C.E., J.E. Staub, P.H. Williams, and M.J. Palmer. 1986. Wisconsin 1983 cucumber. HortScience 21:1082-1083.

Rodgers, J.S. 1972. IV. Measures of genetic similarity and genetic distance. Studies in genetics VII. University of Texas Publ. 7213:145-153.

Rao, C.R. 1964. The use and interpretation of principal component analysis in applied research. Sankhya 26:329-358.

Schapaugh, W.T. 1989. The seed trade's view on proprietary rights, p. 17-23. In: B.E. Caldwell, J.A. Schillinger, J.H. Barton, C.O. Qualset, N.N. Duvick, and R.F. Barnes (eds.). Intellectual property rights associated with plants. Amer. Soc Agron., Madison, Wis. ASA Spec. Publ. 52.

Schiffman, S.S., M.L. Reynolds, and F.W. Young. 1981. Introduction to multidimensional scaling: Theory, methods, and applications. Academic, New York.

Skroch, P., J. Tivang, and J. Neinhuis. 1992. Analysis of genetic relationships using RAPD marker data, p. 12-17. In: J. Neinhuis (ed.). Applications of RAPD technology to plant breeding. Crop Sci. Soc. Amer., Madison, Wis.

Smith, J.J., J.S. Scott-Craig, J.R. Leadbetter, G.L Bush, D.L. Roberts, D.W. Fulbright. 1994. Characterization of random amplified polymorphic DNA (RAPD) products from Xanthomonas campestris and some comments on the use of RAPD products in phylogenetic analysis. Mol. Phylo. Evol. 3:135-145.

Smith, J.S.C. 1984. Genetic variability within U.S. commercial hybrid maize (Zea mays L.): Multivariate analysis of allozyme data. Crop Sci.
2D:1041-1046.

Smith, J.S.C. and O.S. Smith. 1989. The description and assessment of distance between inbred lines of maize: II. The utility of morphological, biochemical and genetic descriptors and a scheme for the testing of distinctiveness between inbred lines. Maydica 34:151-161.

Smith, O.S., J.S.C. Smith, S.L. Bowen, R.A. Tenborg, and S.J. Wall. 1990. Similarities among a group of elite maize inbreds as measured by pedigree, F1 grain yield, grain yield heterosis, and RFLPs. Theor. Appl. Genet. 80:833-840.

Souza, E. and M.E. Sorrells. 1989. Pedigree analysis of North American oat cultivars released from 1951 to 1985. Crop Sci. 29:595-601.

Souza, E. and M.E. Sorrells. 1991a. Relationships among 70 North American oat germplasms. 1. Cluster-analysis using quantitative characters. Crop Sci. 31:599-605.

Souza, E. and M.E. Sorrells. 1991b. Relationships among 70 North American oat germplasms. 2. Cluster-analysis using qualitative characters. Crop Sci. 31:605-612.

Spooner, D.M., D.S. Douches, and A.M. Contreras. 1992. Allozyme variation within Solanum sect. Petota, ser. Etuberosa (Solaneceae). Amer. J. Bot. 79:467-471.

Staub, J.E. 1994. Issues involving genetic distance and plant variety protection. Cucurbitaceae 94 Evaluation and enhancement of cucurbit germplasm. p. 118-123.

Staub, J.E., L.D. Knerr, and H.J. Hopen. 1992. Plant density and herbicides affect cucumber productivity. J. Amer. Soc. Hort. Sci. 117:48-53.

Staub, J.E. and V. Meglic. 1993. Molecular genetic markers and their legal relevance for cultivar discrimination: A case study in cucumber. HortTechnology 3:291-300.

Thormann, C.E., M.E. Ferreira, L.E.A. Camargo, J. G. Tivang, and J.G. Osborne. 1994. Comparison of RFLP and RAPD genetic relationships within and among cruciferous species. Theor. Appl. Genet. 88:973-980.

Tivang, J., J. Nienhuis, and O.S. Smith. 1994. Sampling variances of molecular marker data sets using the bootstrap. Theor. Appl. Genet. 89:259264.

Vanhala, P.T., T. Pehu, and H.G. Gyllenberg. Legal protection of plant biotechnological inventions. J. Agr.. Sci. Fin. 61:405-414.

Webster's Encyclopedic Dictionary. 1990. Lexicon Publications, New York.

Weeden, N.F., G.M. Timmerman, M. Hemmat, B.E. Kneen, and M.A. Lodhi. 1992. Inheritance and reliability of RAPD markers, p. 12-17. In: J. Neinhuis (ed.). Application of RAPD technology to plant breeding. Crop Sci. Soc. Amer., Madison, Wis

Weir, B.S. 1990. Genetic data analysis: Methods for discrete population genetic data. Sinauer Assoc., Sunderland, Mass.

Williams, S.B. and K.A. Weber. 1989. Intellectual property protection and plants, p. 91-107. In: B.E. Caldwell, J.A. Schillinger, J.H. Barton, C.O. Qualset, N.N. Duvick, and R.F. Barnes (eds.). Intellectual property rights associated with plants. Amer. Soc. Agron., Madison, Wis. ASA Special Publ. 52

Wright, S. 1978. Variability within and among natural populations. vol. 4. Evolution and the genetics of populations. Univ. of Chicago Press, Chicago. 